\title{
Oxalis L. (Oxalidaceae) no Estado de Pernambuco, Brasil ${ }^{1}$
}

\author{
Maria Carolina de $\mathrm{Abreu}^{2,4}$, Reginaldo de Carvalho ${ }^{3}$ e Margareth Ferreira de Sales ${ }^{4}$
}

Recebido em 21/12/2006. Aceito em 25/06/2007

\begin{abstract}
RESUMO - (Oxalis L. (Oxalidaceae) no Estado de Pernambuco, Brasil). Este estudo foi baseado na análise morfológica de material herborizado e observação dos espécimes em seu habitat natural. Foram registradas nove espécies diferenciadas, principalmente, pelo sistema caulinar, filotaxia, tipo de folha, cor das flores, tipologia das inflorescências e morfologia das cápsulas. Destas espécies, duas (Oxalis corniculata L. e O. cratensis Oliver ex Hooker) possuem distribuição preferencial nas zonas do Litoral e Mata até a subzona do Agreste. Oxalis psoraleoides Kunth apresenta ampla distribuição em todo Estado. Oxalis triangularis A. St.-Hil. e O. frutescens L. distribuem-se desde as zonas do Litoral e Mata até a subzona do Sertão. Oxalis divaricata Mart. ex Zucc. distribui-se nas subzonas do Agreste e Sertão, ocorrendo também no Arquipélago de Fernando de Noronha. Oxalis hedysarifolia Raddi habita a zona da Mata e a subzona do Agreste apenas em regiões serranas. Oxalis debilis Kunth é restrita a subzona do Agreste e Oxalis glaucescens Norlind é a única com distribuição exclusiva nas caatingas, geralmente, em áreas sedimentares na subzona do Sertão. Chave para identificação, comentários sobre afinidades e distribuição geográfica, bem como ilustrações, são fornecidas.
\end{abstract}

Palavras-chave: Oxalis, Oxalidaceae, taxonomia, Pernambuco, Brasil

\begin{abstract}
Oxalis L. (Oxalidaceae) in Pernambuco State, Brazil). This study was based on morphological analyses from both herbaria and field material. Nine species were recorded, distinguished from each other mainly by the root system, phyllotaxis, leaf type, color of the flowers and inflorescence and capsule morphology. Of these species, two (Oxalis corniculata L. and O. cratensis Oliver ex Hooker) showed preferential distribution from the Litoral and Forest zones to the Agreste subzone. Oxalis psoraleoides Kunth is widely distributed over the entire state. Oxalis triangularis A. St.-Hil. and $O$. frutescens L. are distributed from the Littoral and Forest zones to the Sertão subzone. Oxalis divaricata Mart. ex Zucc. is distributed in the Agreste and Forest subzones, occurring also at Fernando de Noronha Archipelago. Oxalis hedysarifolia Raddi occurs in the Forest zone and in the Agreste subzone, where it is restrict to the mountains. Oxalis debilis Kunth is restricted to the Agreste zone, and Oxalis glaucescens Norlind is the only one found exclusively in sandy caatingas, in the Sertão subzone. Identification keys, comments on the affinities and geographic distribution, as well as illustrations, are presented.
\end{abstract}

Key words: Oxalis, Oxalidaceae, taxonomy, Pernambuco State, Brazil

\section{Introdução}

Oxalidaceae, pertencente à ordem Oxalidales (“eurosids I", APGII 2003), possui aproximadamente 950 espécies, distribuídas em seis gêneros de ampla distribuição (Lourteig 1983). Incluem espécies de hábitos variados e folhas compostas, mais frequentemente trifolioladas (Oxalis L.), mas às vezes uni - bi-folioladas ou pinadas, reflexas durante a noite. Segundo Cronquist (1988), está posicionada na ordem Geraniales, subclasse Rosidae.

Oxalis L. é o maior gênero da família, com cerca de 800 espécies dispersas por todas as regiões do globo, destacando a África e as Américas como centros de diversidade. No Brasil, ocorrem aproximadamente 114 espécies (Lourteig 1994; 2000) conhecidas como "azedinhas" ou "azedeiras", (devido à acidez das plantas), carurus ou ainda trevos ou trevinhos, pelo número (3) e disposição dos folíolos (Knuth 1930; Lourteig 1983). Este gênero inclui plantas de hábito herbáceo ou arbustivo, com caules aéreos ou subterrâneos, folhas compostas (1)-(2)-3-(4-)folioladas, pinadas ou digitadas, cálice e corola pentâmeros, flores amarelas, róseas ou lilases (raramente brancas), estames dez de dois tamanhos, gineceu heterostílico e fruto cápsula (Lourteig 1980a; 1983; 1994; 1995; 2000).

\footnotetext{
Parte da Dissertação de Mestrado da primeira Autora

2 Universidade Federal Rural de Pernambuco, Departamento de Biologia, Área Genética, Rua Dom Manoel de Medeiros s.n., 52171-900 Dois Irmãos, Recife, PE, Brasil (regibio@db.ufrpe.br)

3 Universidade Federal Rural de Pernambuco, Departamento de Biologia, Área Botânica, Rua Dom Manoel de Medeiros s.n., 52171-900 Dois Irmãos, Recife, PE, Brasil (mfsales@db.ufrpe.br)

4 Autor para correspondência: mariacarolinabreu@hotmail.com
} 
A palavra Oxalis foi empregada pela primeira vez por Plínio (Lourteig 1983), e adotada como nome genérico por Linnaeus (1753). Desde então, o gênero foi estudado por diversos autores (Thunberg 1800; Jacquin 1794; Kunth in Humboldt et al. (1822); Candolle 1824; Saint-Hilaire 1825; 1842; Zuccarini 1825; Endlicher 1840; Progel 1877; 1879; Reiche 1894; Knuth 1930; Salter 1944 e Eiten 1963), destacando Lourteig $(1975 ; 1979 ; 1980 b ; 1982 ; 1994 ; 1995 ; 2000)$, que propôs classificações mais recentes e revisou os quatro subgêneros.

A diversidade de Oxalis pode ser evidenciada em floras e sinopses elaboradas para diversos países da Ásia (Veldkamp 1971) e das Américas (Eiten 1963; Romero 1973; Reiche 1898; Robertson 1975; Lourteig 1980a; Burger 1991 e Maidana et al. 2005). No Brasil, estudos abordando a taxonomia de Oxalis são escassos. No entanto, merecem menção os de Progel (1877), que reconheceu 108 espécies em seis seções; Lourteig (1983), Sousa \& Bianchini (2000), Conceição \& Giulietti (1998), e Fiaschi \& Conceição (2005).

Apesar deste gênero ter sido estudado por vários autores e revisado recentemente, foi escolhido como objeto de estudo pela grande quantidade de material sem identificação depositado nos herbários brasileiros. Isto é provavelmente pela dificuldade de reconhecimento das espécies por meio das chaves e descrições, e pela inconsistência dos seus caracteres diagnósticos mencionados na literatura. O presente trabalho objetivou reconhecer a diversidade de Oxalis no estado de Pernambuco, ressaltando caracteres morfológicos e de distribuição geográfica, com o intuito de auxiliar na delimitação e reconhecimento das espécies.

\section{Material e métodos}

O Estado de Pernambuco apresenta uma área superficial de $98.281 \mathrm{~km}^{2}$ e situa-se entre as coordenadas $7^{\circ} 15^{\prime} 45^{\prime \prime}$ - 9 $9^{\circ} 28^{\prime} 18^{\prime \prime}$ S e $34^{\circ} 48^{\prime} 35^{\prime \prime}$ 41 ${ }^{\circ} 19^{\prime} 54^{\prime}$ 'W. Possui clima, solos e fitofisionomias heterogêneas, embora a vegetação de caatinga seja a predominante e ocupe cerca de $70 \%$ do Estado. Na faixa litorânea são encontradas florestas ombrófilas e estacionais, restingas e tipos associados (AndradeLima 1960).

Coletas periódicas foram realizadas nas diferentes zonas fitogeográficas do Estado, entre maio/2005 a outubro/2006, para observação das populações em campo e obtenção de material botânico, seguindo-se metodologia de Mori et al. (1989). Após processamento, o material coletado foi depositado no herbário
Professor Vasconcelos Sobrinho (PEUFR) da Universidade Federal Rural de Pernambuco.

A identificação dos taxa foi baseada em Lourteig (1975; 1979; 1980b; 1982; 1994; 2000) e Progel (1877). Com o intuito de analisar variações morfológicas intraespecíficas, foram examinadas exsicatas provenientes dos seguintes herbários: BHCB, CESJ, EAC, ESAL, HST*, HUEFS, HXBH, IAC, ICBA*, INPA, IPA, MBML, MOSS*, PEUFR, RB, RBR, SP, UB, UEC, UFP, VIC, listados conforme Holmgren et al. (1990) (* não indexados). A padronização da terminologia das estruturas vegetativas e reprodutivas baseou-se em Lawrence (1973), para indumento, e Radford et al. (1974), Bell (1991) e Harris \& Harris (1994), para formas. A heterostilia foi descrita de acordo com Judd et al. (1999) e Proctor et al. (1996). Adotou-se Brummitt \& Powell (1992) para abreviações dos nomes dos autores. As informações contidas nos rótulos das exsicatas auxiliaram para as descrições e comentários sobre a distribuição geográfica. As ilustrações das espécies foram feitas a partir de material coletado e fixado em álcool $70 \%$, além de amostras herborizadas.

\section{Resultados e discussão}

Oxalis L., Sp. Pl. ed 1. 433-435. 1753.

Espécie-Tipo: Oxalis acetosella L. (lectótipo designado por Smith, N. Amer. Fl. 25: 25, 1907).

Ervas, subarbustos ou arbustos. Raízes ramificadas, fibrosas, delgadas ou espessas, carnosas, xilopodiais, tuberculadas ou napiformes nas espécies bulbosas. Caules aéreos, herbáceos ou lenhosos, eretos, rasteiros ou prostrados, ou rizomatosos horizontais ao solo ou verticais e aprofundados formando estolões subterrâneos. Folhas alternas, subopostas, opostas, pseudoverticiladas ou sub-basais nas plantas bulbosas, com ou sem estípulas, digitadas com 3 ou mais folíolos, ou 1-2-3-folioladas, pinadas ou mais raramente inteiras 3-partidas, reflexas durante a noite. Pecíolos cilíndricos, filodiais, ou mais raramente alados, em folhas 3-folioladas. Peciólulos muito curtos, espessados. Folíolos membranáceos, cartáceos ou raramente coriáceos, geralmente obovais ou suborbiculares, ovais a lanceolados, obcordados ou obtriangulares. Indumento de tricomas simples, unicelulares, pluricelulares, capitados ou glandulares. Calosidades, às vezes presentes, em brácteas bulbares, folíolos, brácteas florais, sépalas e raramente pétalas. Inflorescências cimosas, axilares, pedúnculo 
geralmente alongado, constituídas de 1-2-3 ou mais cimas dispostas no ápice do pedúnculo; pedúnculos cilíndricos, filiformes ou alados. Brácteas e bractéolas diminutas. Flores de tamanho variável, heterostílicas (brevistilas, mesostilas e longistilas), actinomorfas, hermafroditas. Pedicelos articulados; cálice 5-partido, sépalas imbricadas, livres, persistentes nos frutos. Pétalas 5, geralmente amarelas, magentas, lilases, róseas ou raramente brancas, livres na base (unha), soldadas na parte mediana, formando um tubo com cinco projeções internamente na união das pétalas; lobos oblongos, obovais ou espatulados, raramente com ápice retuso, glabros, raramente pubescentes ou glandulosos. Estames 10, monadelfos, unidos na base; 5 maiores alternipétalos, pubescentes na porção terminal, com ou sem lígula; 5 menores, opositipétalos, glabros; anteras oblongas ou ovóides, bitecas, deiscência rimosa. Ginóforo pouco desenvolvido; androginóforo às vezes presente. Pistilo único; ovário súpero, 5-carpelar, 5-locular, oval a obclavado, geralmente 5-lobado; óvulos 1-15, pêndulos; estiletes 5 , recurvados nas flores brevistilas, soldados em tamanhos variáveis, parte superior livre, pilosos, persistentes nos frutos; estigmas curtamente 2-fidos, 2-lobulados ou capitados, papilosos. Cápsula loculicida com deiscência explosiva, globosa, ovóide ou cilíndrica, 5-lobada. Sementes marrons, alaranjadas a avermelhadas, em geral ovóides, achatadas dorsiventralmente, testa crustácea diversamente esculturada, longitudinalmente costadas e transversalmente estriadas, com esculturas poligonais, foveoladas, verrucosas ou com estrias transverso-espiraladas ou variantes. Embrião reto, albúmen carnoso.

O gênero Oxalis, segundo Lourteig (1994; 2000), está dividido em quatro subgêneros: Thamnoxys (Endl.) Reiche, Oxalis L., Monoxalis (Small) Lourteig e Trifidus Lourteig. Para Pernambuco, foram encontradas nove espécies distribuídas, de acordo com Lourteig (1994; 2000), em dois subgêneros: Oxalis e Thamnoxys. As espécies de folhas digitadas estão agrupadas no subgênero Oxalis em três seções: Corniculatae DC., caracterizada pela presença de estípulas reduzidas na base do pecíolo ( $O$. corniculata L.); Ionoxalis (Small) Knuth, que inclui as espécies com caules bulbosos ( $O$. debilis Kunth); e Pseudobulbosae Norlind, apresentando representantes com caules bulboso-rizomatosos (O. triangularis A. St.-Hil.). Já as espécies de folhas pinadas estão agrupadas no subgênero Thamnoxys, e segregadas em três seções: Thamnoxys Lourteig, Pleiocarpa Kunth e Psoraleoideae Lourteig. Da primeira seção fazem parte Oxalis cratensis Oliver, O. divaricata Mart. ex Zucc., O. frutescens L. e O. hedysarifolia Raddi por compartilharem inflorescências multifloras, folhas distribuídas ao longo dos ramos ou em braquiblastos, e hábito ereto. $\mathrm{Na}$ segunda inclui-se Oxalis glaucescens Norlind, por apresentar folhas com raque curta (ca. $1 \mathrm{~mm}$ ), cimas uni-bifloras, cápsulas aplainadas e hábito prostrado. $\mathrm{Na}$ última seção (Psoraleoideae) está posicionada Oxalis psoraleoides Kunth, caracterizada, principalmente, pela presença de androginóforo.

Chave para identificação das espécies de Oxalis L. no Estado de Pernambuco

1. Folhas digitadas; cápsulas cilíndrico-elipsóides

2. Pétalas com lobos amarelos; ervas prostradas, estolonífera; estípulas reduzidas, soldadas na base do pecíolo 1. O. corniculata

2. Pétalas com lobos róseos, magenta ou lilases; ervas bulbosas; estípulas ausentes ..... 3

3. Folíolos obtriangulares, esverdeados a vináceos em ambas as faces; bulbos alongados, rizomatosos, estolões presentes 9. O. triangularis

3. Folíolos obcordiformes a obovais, verdes com pontuações enegrecidas na face inferior; bulbos arredondados, estolões ausentes

1. Folhas pinadas; cápsulas globoso-elipsóides, globoso-oblongas, globoso-achatadas ou ovóideglobosas 2. O. cratensis

4. Plantas glabras; pétalas com lobos róseos ou mais raramente brancos 4

4. Plantas indumentadas; pétalas com lobos amarelos a amarelo-intensos 5

5. Ervas prostradas; cimeira unicasial, uni ou biflora; cápsula globoso-achatada, profundamente 5-angulosa 6. O. glaucescens

5. Ervas eretas, subarbustos ou arbustos; cimeira dicasial, multifloras; cápsula ovóide-globosa, globoso-oblonga ou globoso-elipsóide 
6. Folhas verticiladas, 3-5 por nó; ramos com nós em geral congestos, braquiblastos e restos de pecíolos persistentes após a queda dos folíolos 5. O. frutescens

6. Folhas alternas, subopostas ou pseudo-verticiladas; ramos com nós espaçados, braquiblastos ausentes, restos de pecíolos caducos após queda dos folíolos .....

7. Ervas ou raramente subarbustos $15-40 \mathrm{~cm}$; folíolos estreitamente oval-oblongos alineares, raramente obovais 0,7-2,8×0,3-1 cm; ramos híspidos; pétalas 7-9 mm compr.

4. O. divaricata

7. Subarbustos ou arbustos $0,3-2 \mathrm{~m}$; folíolos trulados ou elípticos; 1,9-7,5×0,7-2,8 cm; ramos tomentosos a puberulentos; pétalas 9-35 $\mathrm{mm}$ compr.

8. Folíolos elípticos, nervuras impressas na face superior e proeminentes na inferior; pétalas 13-35 mm compr.; androginóforo presente; cápsulas com uma semente por lóculo.....

8. O. psoraleoides

8. Folíolos trulados, nervuras pouco evidentes em ambas as faces; pétalas $9-12 \mathrm{~mm}$ compr.; androginóforo ausente; cápsulas com 3 sementes por lóculo

7. O. hedysarifolia

1. Oxalis corniculata L., Sp. Pl. ed 1.1: 435. 1753. Fig. 1-8, 75

Ervas prostradas, estoloníferas ou mais raramente eretas, 6-8 cm alt. Ramos cilíndricos, pubescentes; internós $0,3-1,8 \mathrm{~cm}$. Folhas alternas ou pseudoverticiladas, digitadas, trifolioladas; estípulas reduzidas, soldadas na base do pecíolo; pecíolo 1,7-4,3 cm, cilíndrico, pubescente; peciólulos 0,5-1 mm, cilíndricos, densamente pubescentes; folíolos $0,5-1 \times 0,6-1,3 \mathrm{~cm}$, obcordiformes, glabros a pubescentes, verdes ou marrons, base obtusa, ápice obcordado, margem ciliada. Cimas 2-4, multifloras, falsamente umbeliformes; pedúnculo $0,6-4,4 \mathrm{~cm}$, pubescente; brácteas 2 por flor, 1,5-2 mm compr., ovais a lineares, densamente pubescentes. Flores tristílicas; pedicelo $0,6-1 \mathrm{~cm}$, cilíndrico, densamente pubescente. Sépalas 3-4×1-1,2 mm, livres, elípticas a ovais, levemente pubescentes na face externa, glabras na interna. Pétalas 5-8 mm; unha 0,3-0,5 mm, amarela, tubo 1-1,5 mm, amarelo, com estrias alaranjadas internamente; lobos 3-6 mm, espatulados, amarelos. Flores brevistilas: não observadas. Flores mesostilas: estames curtos 3-3,2 mm compr., longos 4-4,2 mm compr.; estiletes 2-2,2 mm, eretos, pubescentes; ovário 1,2-1,3 mm compr.; ginóforo $0,4-0,5 \mathrm{~mm}$. Flores longistilas: estames curtos 2-3 mm compr., longos 3,5-4 mm compr.; estiletes 2-2,2 mm, eretos; ovário 1,2-1,5 mm compr.; ginóforo 0,4-0,5 mm. Estames longos sem lígula; androginóforo ausente; anteras $0,3 \mathrm{~mm}$ compr., oblongo-elípticas. Ovário oblongo, glabro; óvulos 4-12 por lóculo; estigmas bilobados, papilosos. Cápsula 0,4-1,3×0,1-0,3 cm, cilíndrico-elipsóide, tomentosa. Sementes 4-12 por lóculo, 1-2×0,5-1 mm, ovóides, achatadas dorsiventralmente, marrom-avermelhadas, transversalmente estriadas.

Material selecionado: BRASIL. Pernambuco: Arcoverde, 3/VI/2006, fl. fr., Abreu 295 (PEUFR); Camaragibe, 6/III/2006, fl. fr., Abreu \& Nascimento 171 (PEUFR); Caruaru, 10/IX/1971, fl., AndradeLima 71-6465 (IPA); Jaboatão dos Guararapes, 17/IV/2006, fl. fr., Abreu \& Santos 260 (PEUFR); 25/V/2006, fl. fr., Abreu \& Santos 282 (PEUFR); 29/V/2006, fl. fr., Abreu \& Santos 289 (PEUFR); Jupi, 25/VI/2006, fl. fr., Abreu 305 (PEUFR); Sanharó, 7/V/1966, fl. fr., Tenório 66/122 (IPA).

Oxalis corniculata é uma espécie cosmopolita provavelmente de origem européia-mediterrânica. $\mathrm{Na}$ América do Sul possui ampla distribuição, sendo freqüente em ambientes antropizados e jardins (Lourteig 2000). Em Pernambuco, ocorre desde as zonas do Litoral e da Mata até o início do Sertão, em zonas urbanas, associada à construções, como em muros ou frestas de calçadas e, ainda, como invasora de jardins em locais sombreados.

Distingue-se das demais espécies encontradas em Pernambuco pelo hábito herbáceo, pelo caule geralmente prostrado e estolonífero, pelas folhas digitadas e pelas cápsulas cilíndrico-elipsóides. Assemelha-se a $O$. glaucescens por compartilharem o hábito prostrado. No entanto, $O$. glaucescens diferencia-se desta, principalmente, pelas folhas pinadas e cápsulas profundamente 5-angulosas com sépalas persistentes e patentes. É popularmente conhecida como "azedinha". Em Pernambuco floresce e frutifica entre os meses de março e setembro.

2. Oxalis cratensis Oliver ex Hooker, in Hooker, Icon.

Pl. 4: lâm. 361. 1841.

Fig. 9-20, 75 


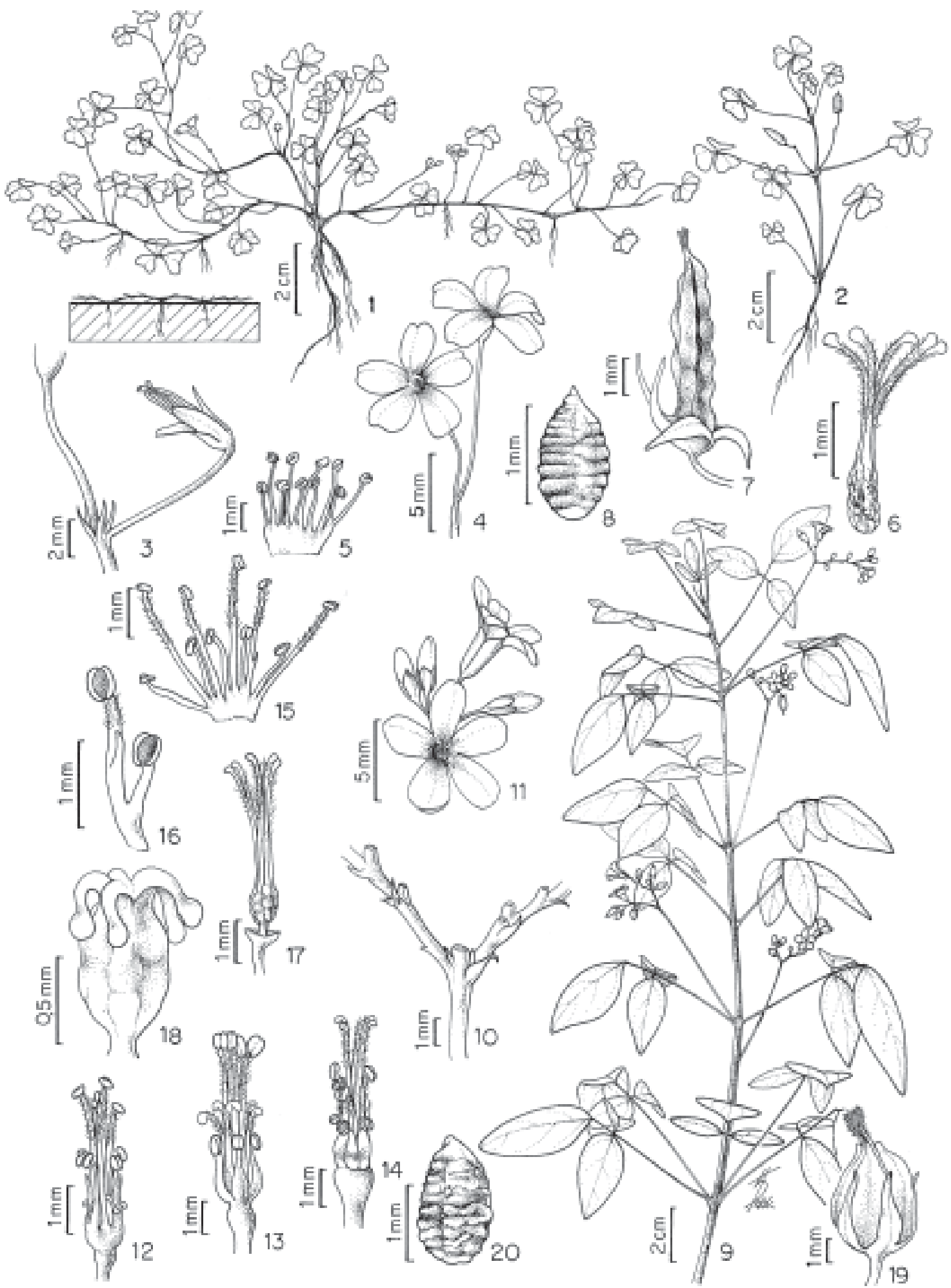

Figuras 1-20. Oxalis corniculata: 1. Hábito planta prostrada, com esquema da vista lateral. 2. Hábito planta ereta. 3. Inflorescência, detalhe. 4. Flores. 5. Androceu evidenciando estames de dois tamanhos. 6. Gineceu. 7 Fruto. 8. Semente (M.C. Abreu 171). O. cratensis: 9. Ramo florido. 10. Inflorescência, detalhe do ápice do pedúnculo. 11. Flores em vista frontal e lateral. 12. Flor brevistila, detalhe androceu e gineceu. 13. Flor mesostila, detalhe androceu e gineceu. 14. Flor longistila, detalhe androceu e gineceu. 15. Androceu, detalhe evidenciando estames maiores com indumento. 16. Estames, detalhe evidenciando estame maior com lígula. 17. Gineceu, flor longistila. 18. Gineceu, flor brevistila. 19. Fruto. 20. Semente (M.C. Abreu 68). 
Ervas ou subarbustos $30-80 \mathrm{~cm}$ alt., eretos, não a pouco ramificados. Ramos glabros; internós $1,5-7,5 \mathrm{~cm}$. Folhas alternas, sub-opostas ou opostas, pinadas, trifolioladas, estípulas ausentes; pecíolo 1,5-4 cm, semicilíndrico, glabro a ligeiramente pubescente; peciólulo 0,7-1 mm compr., semi-cilíndrico a cilíndrico, pubescente; raque foliar 4-8 $\mathrm{mm}$, glabra a ligeiramente pubescente; folíolo terminal 2,1-4,1×0,8-2,1 cm, oval a oval-deltóide, base obtusa a arredondada, ápice agudo a obtuso, margem inteira, glabro; folíolos laterais $0,8-3,5 \times 0,5-1,6 \mathrm{~cm}$, semelhantes ao terminal. Cimeiras dicasiais, 0,4-1,8 cm, multifloras; pedúnculo $1,1-5,8 \mathrm{~cm}$, cilíndrico, glabro; brácteas 1-2 por flor, $1 \mathrm{~mm}$ compr., lanceoladas, glabras a ligeiramente pubescentes, acuminadas. Flores tristílicas; pedicelo 2-4 mm, glabro. Sépalas 3-4×1 mm, livres, oval-lanceoladas, ápice agudo, esverdeadas com bordos róseos ou totalmente róseas, glabras a ligeiramente pubescentes na face externa, glabras na interna. Pétalas 7-10 mm compr.; unha $1 \mathrm{~mm}$, esverdeada; tubo 2-4 mm, amarelo interna e externamente; lobos 4-6 mm, espatulados, róseos ou mais raramente brancos. Flores brevistilas: estames curtos 2-2,5 mm compr., longos 4-4,5 mm compr., estiletes 0,4-0,6 mm, recurvados, glabros; ovário 0,8-1 mm compr.; ginóforo 0,1-0,3 mm. Flores mesostilas: estames curtos 1,5-1,7 mm compr., longos 4-4,2 mm compr.; estiletes ca. $1 \mathrm{~mm}$, eretos, pubescentes; ovário 0,8-1 mm compr.; ginóforo 0,2-0,4 mm. Flores longistilas: estames curtos 1,4-1,7 mm compr., longos 2,4-2,7 mm compr.; estiletes 2,5-3 mm, eretos, pubescentes; ovário 0,9-1,1 mm compr.; ginóforo 0,3-0,5 mm. Estames longos ligulados; androginóforo ausente; anteras $0,5 \mathrm{~mm}$ compr., oblongas. Ovário obclavado, 5-anguloso, glabro; óvulos 3-4 por lóculo; estigmas captados a subcaptados ou bilobados. Cápsula 4-6×3-4 mm, globoso-elipsóide, glabra. Sementes 3-4 por lóculo, 1,8-2×0,8-1 mm, elipsóides, discretamente achatadas dorsiventralmente, costadas, transversalmente estriadas.

Material selecionado: BRASIL. Pernambuco: Aliança, 30/V/2006, fl. fr., Abreu \& Lopes 290 (PEUFR); Arcoverde, 21/VII/1971, fr., Andrade-Lima 71-6300 (IPA); Igarassú, 24/IV/2003, fl., Melquíades \& Bezerra 166 (PEUFR); 14/I/2004, fl., Sá e Silva et al. 249 (PEUFR); Itambé, 3/VIII/1958, fl. fr., Lima s.n. (PEUFR-1266); Moreno, 3/IV/2003, fl. fr., Pereira 23 (IPA); Paulista, 10/IX/1997, fl. fr., Bocage et al. 73 (IPA); Recife, 2/VI/1932, fl., Monteiro 175 (RBR); 3/VIII/1958, fl. fr., Lima s.n. (PEUFR-1267); 25/III/1966, fl. fr., Tenório 66/88 (IPA); 23/VII/1966, fl. fr., Tadeu s.n. (UFP-1799); 19/III/1985, fl. fr., Silva s.n. (UFP-04305); 2/X/1987, fl., Barbosa 10 (UFP); 22/X/1987, fl., Silva s.n. (UFP-7400); 1/III/1988, fl., Soares s.n. (PEUFR-8650); 14/XII/1991, fl. fr., Freitas 534 (UFP); 14/XI/1996, fl. fr., Pedrosa et al. 3 (UFP); 10/II/1997, fl. fr., Araújo et al. 7861 (IPA); 28/X/2001, fl. fr., Albuquerque 3 (UFP); 19/III/2002, f1., Lins s.n. (UFP-33161); 16/V/2005, fl. fr., Abreu \& Alves 66 (PEUFR); 28/VI/2005, fl. fr., Abreu \& Silva 71 (PEUFR); 28/VI/2005, fl. fr., Abreu \& Silva 72 (PEUFR); 28/VI/2005, fl., Abreu \& Silva 73 (PEUFR); 28/VI/2005, fl. fr., Abreu \& Silva 74 (PEUFR); 9/V/2006, fl. fr., Abreu 278 (PEUFR); São Lourenço da Mata, 27/VII/1992, fl., Miranda 515 (HST); São Vicente Férrer, 18/IV/1995, fl., Silva et al. 07 (PEUFR); 3/VI/2005, fl. fr., Abreu \& Lopes 67 (PEUFR); 3/VI/2005, fl. fr., Abreu \& Lopes 68 (PEUFR); Timbaúba, 18/IV/2006, fl. fr., Abreu et al. 264 (PEUFR); Triunfo, 25/II/1986, fl. fr., Gallindo 5 (IPA).

Oxalis cratensis distribui-se pela Bolívia, Paraguai e Brasil, onde pode ser encontrada nas regiões Norte (AM, PA, RR), Nordeste (BA, CE, PE, PI,), Sudeste (ES, MG, SP) e Centro-Oeste (MT) (Lourteig 1994). Em Pernambuco, ocorre nas zonas do Litoral e Mata, na floresta atlântica, em locais sombreados, bordas de mata ou em áreas degradadas e margens de estradas.

Esta espécie é facilmente reconhecida pelo hábito ereto, ramos glabros, flores com tubo amarelo e lobos róseos ou raramente brancos, e pelas cápsulas globosoelipsóides e glabras, com 3-4 sementes por lóculo. Considerando as espécies estudadas, assemelha-se a $O$. hedysarifolia por compartilharem hábito ereto, folhas bem distribuídas ao longo dos ramos, e frutos globoso-elipsóides, embora esta última apresente, em geral, maior porte (30-120 cm alt.), flores amarelas e folíolos trulados. Conhecida popularmente como "azedinha". Floresce e frutifica ao longo de todos os meses do ano.

3. Oxalis debilis Kunth, Nov. Gen. Sp. (quarto ed) 5: 236, ed. Col. 183.1821 (1822).

Fig. 21-28, 75

Erva bulbosa ca. $15-30 \mathrm{~cm}$ alt. Bulbos arredondados, 1-3 cm compr., constituídos de diversos bulbilhos; estolões ausentes; bulbilhos escamosos, escamas externas 3,5-4×3-3,5 mm, membranáceas, oval arredondadas, escamas internas 3-3,5×2,5-3 mm, suculentas, oval arredondadas, com três nervuras alaranjadas. Folhas digitadas, trifolioladas; estípulas ausentes; pecíolo 13-20 cm compr., cilíndrico, viloso; peciólulo 0,7-1 mm compr., cilíndrico, hirsuto; folíolos 
2-3,3×2,5-4 cm, obcordiformes a obovais, verdes, conduplicados apenas à noite, base aguda, ápice retuso, margem ciliada, glabros a pubescentes com pontuações enegrecidas na face inferior. Cimas 2-4, multifloras, umbeliformes; pedúnculo $18-35 \mathrm{~cm}$, cilíndrico, viloso; brácteas 2 por flor, $1-2 \times 0,5 \mathrm{~mm}$, oval-acuminadas, glabras. Flores tristílicas; pedicelo 1-2,4 cm, glabro. Sépalas $4 \times 1-1,5 \mathrm{~mm}$, livres, ovais a oblongas, verdes, ápice com duas calosidades alaranjadas, glabras. Pétalas 1,1-1,4 cm compr.; unha $1 \mathrm{~mm}$, branca; tubo 3-4 mm, esbranquiçado com estrias róseas a lilases; lobos 4-6 mm, espatulados, magenta a lilases. Flores brevistilas: estames curtos 4-4,2 mm compr., longos 5,8-6 mm compr.; estiletes $0,3-0,5 \mathrm{~mm}$, recurvados, glabros; ovário 2-2,3 mm compr.; ginóforo 0,8-1,1 mm. Flores mesostilas: estames curtos 3,5-3,7 mm compr., longos 6-6,5 mm compr.; estiletes 2,5-2,7 mm, eretos, pubescentes; ovário 1,4-1,6 mm compr.; ginóforo 0,4-0,5 mm. Flores longistilas: estames curtos 2-2,3 mm compr., longos 3,5-3,7 mm compr.; estiletes 3-3,2 mm, eretos; ovário 1,3-1,5 mm compr.; ginóforo 0,3-0,4 mm. Estames longos ligulados; androginóforo ausente; anteras 0,3-0,5 mm compr., oblongas. Ovário obclavado, 5-anguloso, pubescente; óvulos 8-12 por lóculo; estigmas capitados a bilobados, papilosos. Cápsula 0,9-1,3×0,2-0,3 cm, cilíndrico-elipsóide, glabra. Sementes 5-10 por lóculo, 1,5-2×0,8-1 mm, elipsóides, achatadas dorsi-ventralmente, longitudinalmente e transversalmente estriados.

Material selecionado: BRASIL. Pernambuco: Caruaru, 10/IX/1971, fl., Andrade-Lima 71-6471 (IPA); 24/II/1994, fl., Costa e Silva 205 (PEUFR); 1/VI/1995, fl., Villarouco et al. 102 (PEUFR); 31/III/2006, fl. Abreu et al. 194 (PEUFR); Sanharó, 7/V/1966, fl., Andrade-Lima 66-4542 (IPA).

De acordo com Lourteig (2000), esta espécie é originária dos Andes tropicais, podendo ser encontrada na América do Sul, Antilhas e Velho Mundo, com ocorrência em áreas cultivadas e em jardins. No Brasil, ocorre principalmente nas regiões Sul (PR, RS, SC) e Sudeste (ES, MG, RJ, SP). Em Pernambuco, foi encontrada em bordas das florestas montanas (Caruaru, a $880 \mathrm{~m}$ alt.), em ambientes úmidos como invasora.

Oxalis debilis é caracterizada por ser uma erva com bulbos arredondados, de onde partem as folhas e os pedúnculos, e ter folíolos obcordados a obovais. Assemelha-se a $O$. triangularis por serem ervas com caules subterrâneos (bulbos), e possuírem cimas umbeliformes e flores com coloração rósea, lilás ou magenta. Diferenciam-se, principalmente, por $O$. triangularis ter bulbos alongados e folíolos obtrian- gulares esverdeados a vináceos. É o popular trevo, sendo conhecida também como "azedinha", "azeidinha" ou "caruru-de-sapo". Em Pernambuco, floresce principalmente entre os meses de novembro a junho.

4. Oxalis divaricata Mart. ex Zucc., Denkscr. Konigl. Akad. Wiss. Munchen Ser. 1. 9:169. 1825.

Fig. 29-39, 75

Ervas ou raramente subarbustos delicados, $15-40 \mathrm{~cm}$ alt., eretos, ramificados. Ramos, alternos, cilíndricos, híspidos, com alguns tricomas glandulares; internós 0,4-3,5 cm . Folhas alternas, sub-opostas, opostas, ou pseudo-verticiladas, pinadas, trifolioladas; pecíolo 0,8-2,3 cm compr., cilíndrico-canaliculado, híspido; peciólulo 0,5-0,8 $\mathrm{mm}$, cilíndrico, híspido a esparsamente glandular-pubescente; raque 1-4 mm, híspida a pubescente; folíolo terminal 0,7-2,8×0,3-1 cm, estreitamente oval-oblongo a linear, ou raramente oboval, base aguda, ápice retuso, agudo a obtuso, margem inteira, glabro a ligeiramente pubescente na nervura principal na face inferior; folíolos laterais 0,5-2,2×0,1-0,8 cm, semelhantes ao terminal. Cimeiras dicasiais, $0,5-1,6 \mathrm{~cm}$, multifloras; pedúnculo 2,8-4,8 cm, canaliculado, híspido; brácteas 1-2 por flor, 0,5-1 mm compr., lanceoladas, agudas. Flores tristílicas; pedicelo 1,5-3 mm, hirsuto a pubescente, vináceo ou verde. Sépalas 3-4,3×1-1,5 mm, livres, oval-lanceoladas a ovais, ápice agudo, esverdeadas, verdes com bordos vináceos ou vináceas, glabras internamente, hirsutas a glandular-pubescentes na face externa, glabras na interna. Pétalas 7-9 mm compr.; unha ca. $1 \mathrm{~mm}$, amarelo-esverdeada, tubo 3-4 mm, amarelo, com estrias alaranjadas internamente; lobos 4-5 mm, espatulados, amarelo-intensos. Flores brevistilas: estames curtos 1,5-2,5 mm compr., longos 3-3,3 mm compr., estiletes $0,3-0,5 \mathrm{~mm}$, recurvados, glabros; ovário 0,8-1 mm compr.; ginóforo 0,2-0,8 mm. Flores mesostilas: estames curtos 1-1,5 mm compr., longos 3-3,5 mm compr.; estiletes 1-1,2 mm, eretos, pubescentes; ovário 0,8-1 mm compr.; ginóforo $0,3-0,8 \mathrm{~mm}$. Flores longistilas: estames curtos 1-1,5 mm compr., longos 2-2,5 mm compr.; estiletes 2-2,5 mm, eretos, pubescentes; ovário 0,4-0,6 mm compr.; ginóforo 0,2-0,5 mm. Estames longos ligulados; androginóforo ausente; anteras 0,2-0,5 mm compr., oblongas. Ovário obclavado, 5-anguloso, glabro; óvulos 3 por lóculo; estigmas bilobados. Cápsula 3-4,5x 4-5 mm, globoso-elipsóide, pubescente. Sementes 2 por lóculo, 1-2×0,5-1 mm, ovóides, marrom a alaranjadas, 3 -costadas longitudinalmente, transversalmente estriadas em zig-zag. 


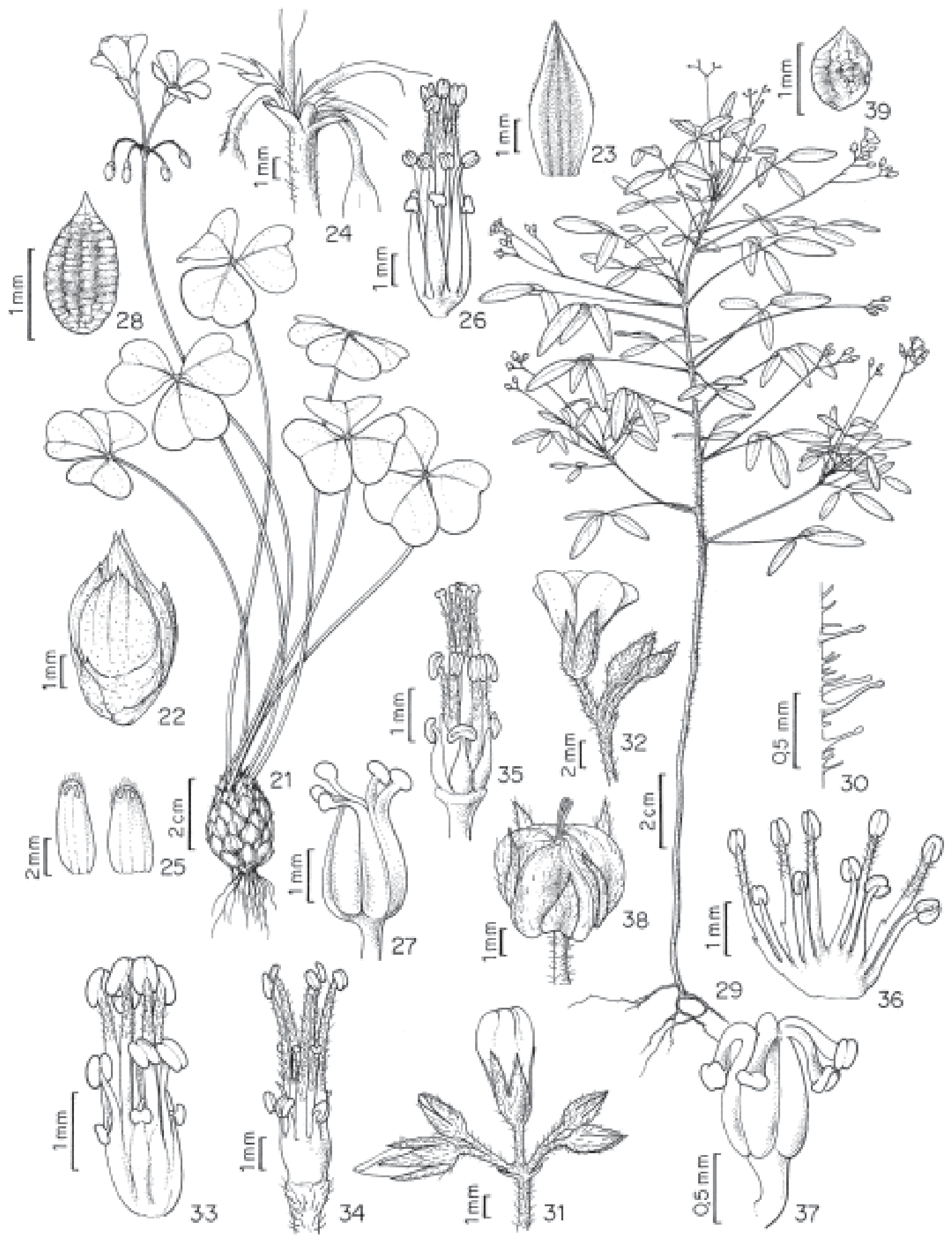

Figuras 21-39. Oxalis debilis: 21. Hábito. 22. Bulbilho evidenciando escamas. 23. Escama externa do bulbilho. 24. Inflorescência, detalhe do ápice do pedúnculo floral. 25. Sépalas, evidenciando ápice com calosidades. 26. Flor brevistila, detalhe do androceu e gineceu. 27. Gineceu, flor brevistila. 28. Semente (M.C. Abreu 194). O. divaricata: 29. Hábito. 30. Tricomas glandulares, detalhe. 31. Inflorescência, detalhe da cimeira. 32. Flor. 33. Flor brevistila, detalhe do androceu e gineceu. 34. Flor mesostila, detalhe do androceu e gineceu. 35. Flor longistila, detalhe do androceu e gineceu. 36. Androceu evidenciando estames longos com indumento e lígula. 37. Gineceu, flor brevistila. 38. Fruto. 39. Semente (M.C. Abreu 350). 
Material selecionado: BRASIL. Pernambuco: Afrânio, 1984, fl. fr., Pereira s.n. (IPA-49860); Alagoa de Baixo, 9/III/1933, fl., Monteiro 303 (RBR); Bezerros, 13/XI/1993, fl., Miranda 1107 (HST); 13/IV/1997, fl., Miranda et al. 2647 (IPA); Brejo da Madre de Deus, 13/XI/1993, fl. fr., Miranda 1107 (PEUFR); Bom Conselho, 8/X/1961, fl. fr., AndradeLima 1-3958 (IPA); Buíque, 11/VII/1997, fl. fr., Lacerda et al. 11 (HST); 26/VII/2005, fl. fr., Abreu et al. 122 (PEUFR); Caruaru, 1/VIII/1996, fl., Oliveira et al. 14 (HST); Fernando de Noronha, VII/1890, fl., R.L.D.R 15 (IPA); 8/IV/1999, fl., Miranda 3226 (HST); 17/VI/2003, fl. fr., Miranda 4088 (HST); Ibimirim, 6/VI/1982, fr., Ataíde et al. 18 (IPA); 16/VI/2005, fl. fr., Melo \& Silva 527 (PEUFR); 1/VII/2006, fl. fr., Abreu et al. 340 (PEUFR); 1/VII/2006, fl. fr., Abreu et al. 344 (PEUFR); Ouricuri, 1/V/1971, fl. fr., Heringer et al. 428 (IPA, PEUFR, RB, UB); 5/V/1971, fr., Heringer et al. 522 (IPA); 10/III/1982, fl., Lima et al. 39 (IPA, PEUFR); Parnamirim, 21/V/1984, fl. fr., Araújo 70 (IPA); Pedra, 2/VII/2006, fl. fr., Abreu et al. 350 (PEUFR); Pesqueira, 23/II/1962, fl., Mattos \& Mattos s.n. (SP76278); 27/VI/1995, fl. fr., Correa \& Moura 243 (IPA, PEUFR, UFP); Serra Talhada, 1982, fl. fr., Queiroz s.n. (IPA-45266); 7/VI/1983, fl., Araújo 8 (IPA); 2/IV/2001, fl. fr., Harley \& Giulietti 54123 (PEUFR); 10/VI/2006, fl., Abreu et al. 296 (PEUFR); Sertânia, 20/VI/2000, fl., Barreto et al. 13 (IPA); Taquaritinga do Norte, 14/VII/2006, fl. fr., Abreu et al. 355 (PEUFR).

Espécie restrita ao Brasil, com ocorrência nas regiões Nordeste (BA, CE, MA, PB, PE, PI), CentroOeste (GO) e Sudeste (MG, RJ). Em Pernambuco, ocorre apenas na zona das Caatingas (Agreste e Sertão), em locais arenosos e sombreados da caatinga arbustivo-arbórea e áreas antropizadas e no Arquipélago de Fernando de Noronha.

Pode ser reconhecida pelo hábito herbáceo ou raramente subarbustivo delicado, pelos tricomas glandulares nos ramos e sépalas, folíolos glabros a levemente pubescentes na nervura principal, e flores amarelas. Às vezes pode ser confundida com alguns indivíduos subarbustivos de $O$. frutescens pelas flores amarelo-intensas. No entanto, diferenciam-se por esta última ter os nós congestos com braquiblastos, restos de pecíolos e folíolos com face inferior serícea. Foi encontrada com flores e frutos durante o ano inteiro.

5. Oxalis frutescens L., Sp. Pl. ed. 1. 435. 1753. Fig. 40-48, 75
Arbustos, subarbustos ou mais raramente ervas eretas, 6-40 $\mathrm{cm}$ alt., em geral bastante ramificado. Ramos cilíndricos, seríceos; internós 0,6-7 cm compr., nós em geral congestos de onde partem 3-5 folhas, 1-3 ramos encurtados (braquiblastos) e restos de pecíolos; braquiblastos $0,3-1,5 \mathrm{~cm}$, ausentes nos nós apicais. Folhas verticiladas, 3-5 por nó, pinadas, trifolioladas; pecíolo 0,6-1,7 cm compr., cilíndrico, hirsuto, persistente após a queda dos folíolos; peciólulos 0,5-0,8 mm compr., cilíndrico, glabro; raque 2-6 mm compr., hirsuta; folíolo terminal 0,4-2,1×0,3-1 cm, ovalelíptico, seríceo na face inferior e ligeiramente seríceo na face superior, base aguda, ápice retuso, margem ciliada; folíolos laterais $0,4-1,5 \times 0,3-0,8 \mathrm{~cm}$, semelhantes ao terminal. Cimeiras dicasiais, $3-5 \mathrm{~mm}$, multifloras; pedúnculo $0,5-1,9 \mathrm{~cm}$, hirsuto, cilindrico; brácteas 1-2 por flor, $1,5-2 \times 0,5 \mathrm{~mm}$, lanceoladas. Flores tristílicas; pedicelo 2-4 mm, hirsuto. Sépalas 4-5×1-2 mm, livres, oval-acuminadas, hirsutas. Pétalas 6-12 mm compr., unhas 1-1,5 mm, amarelas; tubo 3-4 mm, amarelo, com estrias alaranjadas internamente; lobos 4-7 mm, espatulados, amarelo-intensos. Flores brevistilas: estames curtos 3-3,5 mm compr., longos 4,8-5,1 mm compr., estiletes $0,3-0,7 \mathrm{~mm}$, recurvados, glabros; ovário 0,8-1 mm compr.; ginóforo 0,2-0,5 mm. Flores mesostilas: estames curtos 1,1-2 mm compr., longos 4,2-6 mm compr., pubescentes; estiletes 1,4-1,8 mm, eretos, pubescentes; ovário 0,7-1,1 mm compr.; ginóforo 0,4-0,6 mm. Flores longistilas: estames curtos 1-1,2 mm compr., longos 2,8-3 mm compr.; estiletes 3-3,5 mm, eretos, pubescentes; ovário 0,8-1 mm compr.; ginóforo 0,2-0,3 mm. Estames longos ligulados; androginóforo ausente; anteras 0,4-0,5 mm compr., oblongas. Ovário obclavado a globoso, 5-anguloso, glabro; óvulos 2-5 por lóculo; estigmas capitados a subcapitados ou bilobados. Cápsula 3-7×3-4 mm, globoso-oblonga, glabra a pubescente. Sementes 2-4 por lóculo, 1-1,5×0,5-0,9 mm, oval-elipsóides, 5-costadas longitudinalmente, transversalmente estriadas.

Material selecionado: BRASIL. Pernambuco: Afrânio, 24/IV/1971, fl. fr., Heringer 332 (PEUFR, RB, UB); Agrestina, 21/III/2005, fl., Melo s.n. (UFP51505); Arcoverde, 11/VII/1997, fl., Borba s.n. (HST6965); Belo Jardim, 26/V/1993, fl., Miranda 476 (PEUFR); Brejo da Madre de Deus, 28/III/2000, fl. fr., Nascimento \& Silva 358 (PEUFR); Buíque, 19/VI/1994, fl. fr., Miranda et al. 1734 (HST, PEUFR); 19/X/1994, fl. fr., Sales 436 (PEUFR); 11/II/1995, fl. fr., Rodal et al. 462 (PEUFR); 17/VIII/1995, fl. fr., Figueiredo et al. 136 (PEUFR); 24/VII/2004, fl. fr., Melo 454 (PEUFR); 26/VII/2005, 
fl. fr., Abreu et al. 83 (PEUFR); Caruaru, 31/III/2006, fl. fr., Abreu et al. 193 (PEUFR); Cruzeiro do Nordeste, 3/VIII/1996, Oliveira et al. 64 (HST); Garanhuns, 11/IV/2006, fl. fr., Abreu \& Alves 256 (PEUFR); Gravatá, 25/VIII/1970, fl., Mariz s.n. (UFP3020); 8/IV/1994, fl. fr., Miranda et al. s.n. (PEUFR16588); 18/VI/1994, fl. fr., Miranda et al. 1697 (HST, PEUFR); 29/IV/1996, fl., Lima 17 (HST); 11/V/1998, fl. Félix 8399 (HST); 25/V/2006, fl. fr., Abreu et al. 284 (PEUFR); Pombos, 19/X/2002, fl., Alves s.n. (UFP-33782); São Lourenço da Mata, 10/II/2004, fl., Sobrinho 497 (UFP); Vitória de Santo Antão, 13/X/1961, fl. fr., Sarmento 449 (PEUFR); 25/IX/1976, fl. fr., Davis \& Lima 61082 (UEC).

Distribui-se desde o México e Antilhas até o Noroeste da Argentina em Cerrados, Campos e Floresta úmida (Lourteig 1994). No Brasil, ocorre nas regiões Norte (AM, AP, RR), Nordeste (BA, CE, MA, PE, PI), Centro-Oeste (MT) e Sudeste (MG, RJ). Em Pernambuco, é encontrada desde a zona da Mata, em florestas secundárias, até a subzona do Sertão, na zona das Caatingas, em diferentes fisionomias deste bioma.

Oxalis frutescens é de fácil reconhecimento por apresentar nós congestos de onde partem um a três ramos encurtados (braquiblastos), três ou mais folhas, inflorescências e restos de pecíolos que perderam os folíolos. É conhecido popularmente como "vinagreirado-camaleão". Em Pernambuco, floresce e frutifica nos meses de fevereiro a outubro.

6. Oxalis glaucescens Norlind, Ark. Bot. 14(6): 15-16, lâm. 4, fig. 2. 1915.

Fig. 49-54, 75

Ervas perenes, prostradas, $6-15 \mathrm{~cm}$ de altura. Ramos numerosos, partindo da porção proximal do caule, alguns ascendentes, cilíndricos a ligeiramente sulcados, tomentosos; internós 0,1-6,3 cm. Folhas opostas a pseudoverticiladas, pinadas, trifolioladas; pecíolo 1-1,8 cm, cilíndrico, tomentoso; peciólulos 0,3-0,5 mm compr., cilíndricos, glabros; raque 1-2 mm; folíolo terminal $0,5-1,1 \times 0,8-1,3 \mathrm{~cm}$, acentuadamente obcordiforme a obcordado, piloso, base aguda, ápice emarginado, margem ciliada; folíolos laterais $0,4-1 \times$ 0,7-1,1 cm, semelhantes ao terminal. Cimeiras unicasiais, 0,1-0,2 cm, uni ou biflora; pedúnculo 0,6$1,8 \mathrm{~cm}$, piloso; brácteas 2 por flor, 2-3 mm compr., lineares, tomentosas. Flores distílicas (Lourteig 1994); pedicelo 2-3,5 mm, tomentoso. Sépalas 3-4×2-2,5 mm, livres, oval-elípticas, hirsutas na face externa, glabras na face interna. Pétalas 4,2-7 mm; unha 1-1,5 mm, esverdeada; tubo $2-4 \mathrm{~mm}$, amarelo, com estrias alaranjadas internamente; lobos 2-4 mm, obovados a levemente espatulados, amarelos. Flores brevistilas: estames curtos 1-1,5 mm compr., glabros, longos 2-2,3 mm, pubescentes, ligulados; androginóforo ausente; anteras 0,4-0,5 mm compr., oblongo-elípticas. Ovário 0,5-0,7 mm compr., globoso-piriforme, puberulento, óvulo 1 por lóculo; estiletes 0,8-1,2 mm compr., puberulentos; estigmas discóides; ginóforo 0,5-0,8 mm. Flores longistilas: não observadas. Cápsula 4,5-6×3-5,5 mm, globoso-achatada, profundamente 5 -angulosa, pubescente, sépalas persistentes, patentes. Semente uma por lóculo, 1,8-2×0,9-1 mm, elipsóide, 5-6 costada.

Material selecionado: BRASIL. Pernambuco: Bethânia, 23/III/2006, fl. fr., Pessoa 325 (PEUFR); Bodocó, 16/VII/1962, fr., Eiten \& Eiten 4932 (SP, UB); Ouricuri, 1984, fr., Lima 84 (IPA); Parnamirim, 30/IV/1984, fl. fr., Araújo 37 (IPA); Petrolina, 1979, fl. fr., Andrade-Lima et al. 79-9214 (IPA); Serra Talhada, 15/V/1968, fr., Lira 68-225 (IPA); 1988, fl. fr., Queiroz s.n. (IPA-5184); 2/IV/2001, fl. fr., Harley \& Giulietti 54128 (HUEFS); 10/VI/2006, fl. fr., Abreu et al. 300 (PEUFR); Entre Serra Talhada e Petrolina, 17/IV/1971, fl. fr., Heringer et al. 3 (IPA, PEUFR, RB, UB); Sertânia, VII/2003, fl. fr., Melo \& Karlo 32 (IPA); 16/VI/2005, fl. fr., Silva \& Melo 635 (PEUFR); s.m. Arredores da Lagoa de Baixo, 9/III/1933, fl. fr., Monteiro 268 (PEUFR).

Espécie exclusiva do Brasil, com ocorrência nas regiões Nordeste (BA, CE, PE, PI), em vegetação de Caatinga, Centro-Oeste (MT) e Sudeste (MG), em Cerrado. Em Pernambuco, ocorre exclusivamente na zona das Caatingas, subzona do Sertão em locais sombreados, em geral em áreas sedimentares. É facilmente reconhecida pelo hábito herbáceo prostrado, com ramos partindo da porção proximal do caule, e pela cápsula globoso-achatada, profundamente 5-angulosa, com sépalas persistentes e patentes. Em Pernambuco, floresce e frutifica entre março e julho.

7. Oxalis hedysarifolia Raddi, Mem. Mat. Fis. Soc. Ital. Sci. Modena, Pt. Mem. Fis. 18 (2): 401. 1820, não Kunth, Nov. Gen. Sp. (quarto ed) 5: 247-248. 1821 (1822). nem Pohl ex Progel, Fl. Bras. 12(2):504. 1877.

Fig. 55-60, 75

Arbustos ou subarbustos, 0,3-1,2 m alt., pouco ramificados. Ramos cilíndricos, sulcados nas porções terminais, cicatrizes proeminentes das folhas e ramos caídos, tomentosos; internós 1,5-2,4 cm. Folhas alternas, pinadas, trifolioladas, bem distribuídas ao longo 


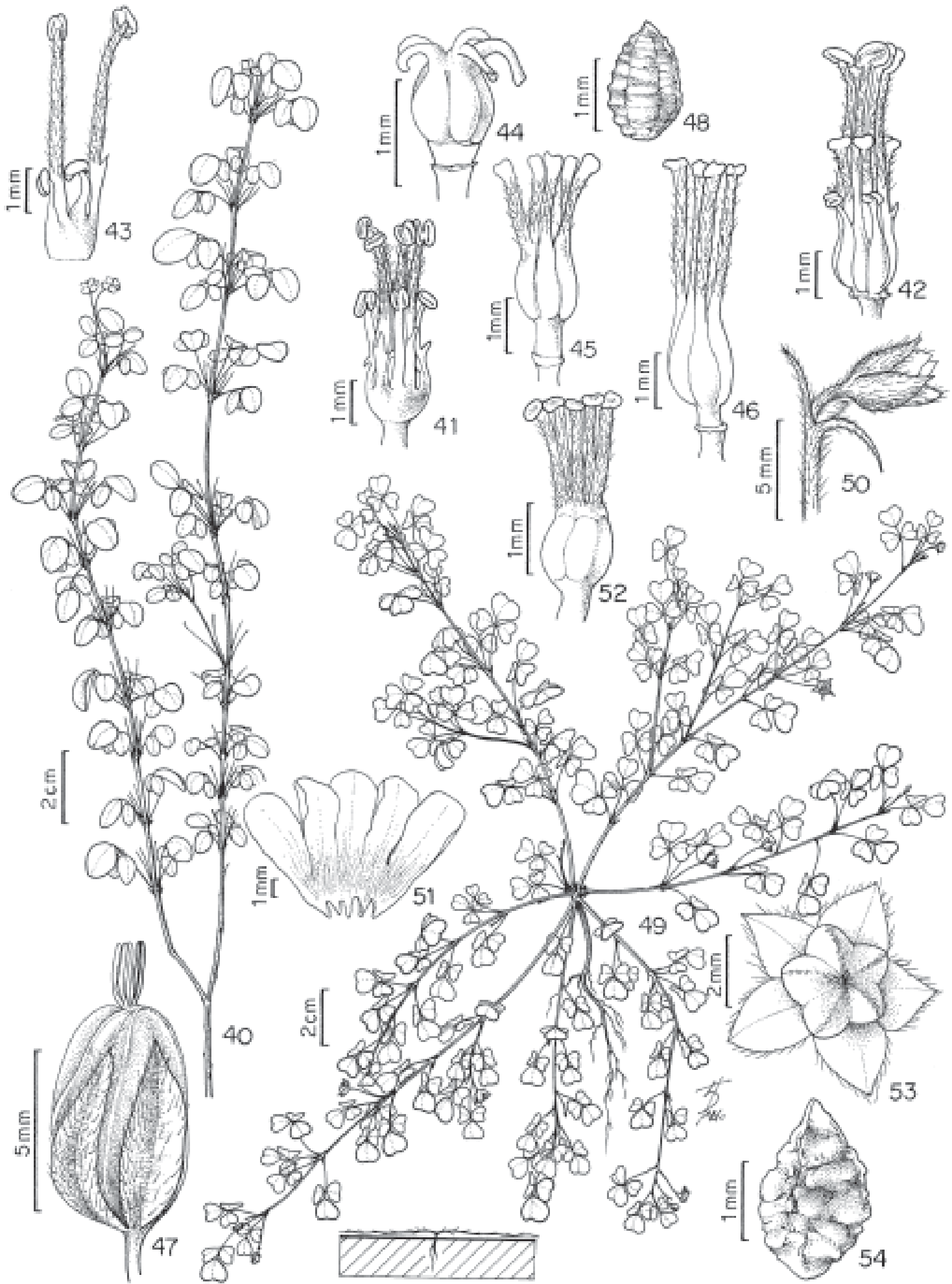

Figuras 40-54. Oxalis frutescens: 40. Ramo florido. 41. Flor brevistila, detalhe do androceu e gineceu. 42. Flor mesostila, detalhe do androceu e gineceu. 43. Androceu, detalhe dos estames longos com indumento e lígula. 44. Gineceu, flor brevistila. 45. Gineceu, flor mesostila. 46. Gineceu, flor longistila. 47. Fruto. 48. Semente (M.C.Abreu 193). O. glaucescens: 49. Hábito, em vista frontal com esquema da vista lateral (abaixo). 50. Inflorescência. 51. Corola evidenciando pétalas com unha. 52. Gineceu. 53. Fruto vista apical. 54. Semente (L.M. Pessoa 325). 
dos ramos; pecíolo 2,3-4,2 cm, ligeiramente sulcado, pubescente; peciólulo 1-2 mm compr., cilíndrico, pubescente; raque 3-7 mm, pubescente; folíolo terminal 1,9-4,6×0,7-1,7 cm, trulado, com nervuras pouco evidentes em ambas as faces, base obtusa, ápice agudo, margem inteira, face superior pubescente a glabrescente, inferior velutina a serícea; folíolos laterais 1,2-2,9×0,5-1,5 cm, semelhantes ao terminal. Cimeiras dicasiais, 0,2-2 cm, multifloras; pedúnculo 4,5-6,8 cm, cilíndrico, pubescente; brácteas 1-2 por flor, 0,5-1 mm compr., oval-acuminadas, pubescentes. Flores tristílicas; pedicelo 3-4 mm, glabro. Sépalas 3-4,5x 1-2 mm, oval-elípticas, pubescentes na face externa, glabras na interna. Pétalas 9-12 mm compr.; unhas 1-2 $\mathrm{mm}$, amarelas; tubo 3-4 $\mathrm{mm}$, amarelo, com nervuras alaranjadas internamente; lobos 4,5-6 mm, espatulados, amarelos. Flores brevistilas: estames curtos 2-3 mm compr., longos 5-5,5 mm compr.; estiletes $0,5-1 \mathrm{~mm}$ compr., recurvados, glabros; ovário 0,8-1 mm compr.; ginóforo 0,1-0,2 mm compr. Flores mesostilas: estames curtos 1-2 mm compr., longos 4-5 mm compr., estiletes 2-2,3 $\mathrm{mm}$, eretos, pubescentes; ovário 1-1,2 mm compr.; ginóforo 0,1-0,5 mm compr. Flores longistilas: estames curtos 1,7-1,8 mm compr., longos 2,5-3,2 mm compr; estiletes 2,5-3,2 mm, eretos, pubescentes; ovário 0,8-1,1 mm compr.; ginóforo 0,2-0,4 mm compr. Estames longos ligulados; androginóforo ausente; anteras $0,5 \mathrm{~mm}$ compr., oblongas. Ovário, obclavado, 5-anguloso, glabro; óvulos 3 por lóculo; estigmas bilobados. Cápsula 7-8×4,5-5 mm, globoso-elipsóide, glabra. Sementes 3 por lóculo, $2 \times 1,5 \mathrm{~mm}$, ovóides, achatadas dorsiventralmente, 8-costadas longitudinalmente, transversalmente estriadas.

Material selecionado: BRASIL. Pernambuco: Altinho, 1/XI/1996, fl., Baracho s.n. (UFP-16239); Barreiros, 5/I/2000, fl., Lucena et al. 791 (PEUFR); 27/IX/2004, fl. fr., Melo 467 (PEUFR); Bezerros, 18/III/1995, fl. fr., Félix \& Paula 7062 (HST); 12/IV/1995, fl., Sales et al. 570 (PEUFR); 12/IV/1995, fl. fr., Villarouco et al. 37 (PEUFR); 2/VI/1995, fl., Melo \& Anania 67 (PEUFR); 2/VI/1995, fl. fr., Oliveira \& Ramalho 46 (PEUFR); 5/X/1995, fl., Inácio 73 (PEUFR); 5/X/1995, fl., Silva et al. 67 (PEUFR); 8/II/1996, fl., Lira \& Oliveira 112 (PEUFR); 20/VI/1996, fl. fr., Marcon et al. 186 (PEUFR); 20/VI/1996, fl., Silva \& Marcon 244 (PEUFR); 13/IV/1997, fl., Miranda et al. 2647 (HST); 17/VIII/1999, fl. fr., Krause \& Liebig 65 (PEUFR); Brejo da Madre de Deus, 6/VIII/1968, fl. fr., Lira 68-284 (IPA); 14/III/1996, fl. fr., Silva et al.
170 (PEUFR); 15/III/1996, fl. fr., Inácio et al. 196 (PEUFR); 15/III/1996, fl. fr., Silva et al. 187 (PEUFR); 16/III/1996, fl. fr., Inácio et al. 213 (PEUFR); 16/III/1996, fl., Tschá et al. 716 (PEUFR); 29/III/1996, fl. fr., Souza et al. 104 (PEUFR); 15/V/1999, fl., Nascimento \& Silva 228 (PEUFR); 28/III/2000, fl. fr., Nascimento \& Silva 357 (PEUFR); 05/IX/2000, fl., Silva et al. 323 (PEUFR); 4/IV/2006, fl. fr., Abreu 212 (PEUFR); Caruaru, 22/VII/1994, fl., Sales \& Rodal 231 (PEUFR); 2/VI/1995, fl. fr., Melo 67 (PEUFR); Lagoa dos Gatos, 21/IV/1994, fl. fr., Miranda \& Félix 1651 (PEUFR); Maraial, 8/XI/1996, fl., Siqueira Filho \& Baracho s.n. (UFP-15799); 8/X/2004, fl., Leite \& Oliveira 10 (UFP); Quipapá, 12/VII/1950, fl., Leal \& Silva 226 (RB).

Oxalis hedysarifolia distribui-se na Bolívia, Brasil e Paraguai, em florestas úmidas, cerrados e restingas (Lourteig 1994). No Brasil, está amplamente distribuída nas regiões Norte (PA, RO), Nordeste (BA, CE, MA, $\mathrm{PB}, \mathrm{PE}$ ), Centro-Oeste (GO, MT), Sudeste (MG, RJ, SP) e Sul (SC), ocorrendo nas florestas atlântica e amazônica e nos cerrados. Em Pernambuco, ocorre na subzona do Agreste sobre serras, em florestas montanas (Brejo da Madre de Deus, Caruaru e Bezerros) e na zona da Mata em florestas costeiras, em bordas e interior de mata.

Esta espécie é facilmente reconhecida pelos folíolos trulados com nervuras pouco evidentes, ramos tomentosos e cápsulas globoso-elipsóides com 3 sementes. Conhecida como "trevo-azedo", floresce e frutifica durante o ano inteiro em Pernambuco.

8. Oxalis psoraleoides Kunth, Nov. Gen. Sp. (quarto ed). 5: 246, lám 470, 1821 (1822), não Mart., Flora 20 (Beibl. 2): 124. 1837.

Fig. 61-69, 75

Arbustos 0,6-2 m alt. Ramos cilíndricos, tomentosos a puberulentos nas porções mais velhas; internós 0,4-4 cm. Folhas alternas, pinadas, trifolioladas, bem dispersas ao longo do caule, discolores; pecíolo 3-6,5 cm, cilíndrico a levemente sulcado, tomentoso a hirsuto; peciólulo 1-2 mm compr., cilíndrico, hirsuto; raque $0,7-1,5 \mathrm{~cm}$, tomentosa; folíolo terminal 3-7,5×1,2-2,8 cm, elíptico, face superior serícea com nervuras impressas, inferior densa a esparsamente serícea ou pubescente com nervuras proeminentes, base levemente oblíqua, ápice acuminado, margem inteira; folíolos laterais 2,2-6,8×1,2-3 cm, semelhantes ao terminal. Cimeiras dicasiais, $0,5-3 \mathrm{~cm}$, multifloras; pedúnculo $3,8-7,8 \mathrm{~cm}$, canaliculado, tomentoso; brácteas 1-2 por flor, 2-2,5 mm compr., ovais, seríceas. 
Flores tristílicas; pedicelo 3-5 mm, seríceo. Sépalas 2,5-4×6-9 mm, ovais, elípticas ou oblongas, seríceas na face externa, glabras na interna. Pétalas 13-35 mm; unhas ca. $2 \mathrm{~mm}$, amarelas; tubo 3-6 mm, amarelo internamente; lobos 1-2,7 cm, obovais a espatulados, amarelos. Flores brevistilas: estames curtos 4-4,5 mm compr., longos 6-7 mm compr.; estiletes 0,5-1 mm, recurvados, glabros; ovário 1,3-2 mm compr.; ginóforo 0,5-1,5 mm. Flores mesostilas: estames curtos, 2,5-3 mm compr., longos, 4-7 $\mathrm{mm}$ compr.; estiletes 2-2,5 mm, eretos, pubescentes; ovário 1-1,5 mm compr.; ginóforo 1-1,5 mm. Flores longistilas: estames curtos 2-2,5 mm compr., longos 4-4,5 mm compr.; estiletes 4-5 mm, eretos, pubescentes; ovário ca. $2 \mathrm{~mm}$ compr., ginóforo 1-1,5 mm. Estames longos ligulados; androginóforo 0,1-0,4 mm, anteras 0,5-1 mm compr., ovóides. Ovário oval, pubescente a glabro, um óvulo por lóculo; estigmas subcapitados, papilosos. Cápsula 6-8×6 mm, ovóide-globosa, glabra. Semente uma por lóculo, $4 \times 2,5 \mathrm{~mm}$, ovóide a elipsóide, achatada, com pontuações transversais.

Material selecionado: BRASIL. Pernambuco: Afrânio, 20/IV/1971, fr., Heringer et al. 203 (PEUFR, UB); Águas Belas, 12/V/2000, fl. fr., Lima s.n. (IPA65552); 30/VI/2006, fl. fr., Abreu et al. 316 (PEUFR); Alagoinha, 17/V/1995, fl. fr., Griz et al. 24 (IPA); 21/VII/1999, fl., Albuquerque et al. s.n. (UFP-24838); 5/VII/2001, fl., Silva et al. s.n. (UFP-31190); Araripina, 7/III/1970, fl., Eiten \& Eiten 10857 (SP, UB); Arcoverde, 08/V/1950, fl., Andrade-Lima 50-531 (IPA); 11/VIII/1981, fl., Cavalcanti s.n. (IPA-45403); 11/VIII/1981, fl., Grécia s.n. (IPA-45386); 11/VIII/1981, fl. fr., Grécia s.n. (IPA-45384); 2/VIII/1996, fl. fr., Miranda et al s.n. (HST-6992); 2/VII/2006, fl. fr., Abreu et al. 348 (PEUFR); Belo Jardim, 1/XI/1986, fl., Webster 25636 (IPA); 3/VI/1993, fl., Miranda et al 474 (HST); 29/IV/1996, fl., Félix et al s.n. (IPA-58006, HST-5286); s.d., fl. fr., Miranda et al. 474 (IPA); Bezerros, 27/VII/1988, fl., Pereira 255 (IPA); 12/IV/1997, fl., Miranda et al. 2646 (HST); 25/V/2006, fl. fr., Abreu et al. 285 (PEUFR); Bom Conselho, 9/X/1961, fl. fr., AndradeLima 61-3962 (IPA); Brejo da Madre de Deus, 14/IV/1936, fl., Guilde 4162 (IPA); 11/I/1982, fl. fr., Giullietti et al. s.n. (IPA-32093, PEUFR-6635); Camocim de São Félix, 20/X/1995, fl., Miranda et al. 2337 (HST); Caruaru, 18/IV/1997, fl., Laurênio et al. 479 (PEUFR); s.d., fl., Pickel 959 (IPA); Cupira, 25/IX/1976, fl., Davis \& Lima 61125 (UEC); Fernando de Noronha, 18/X/1955, fl., Lima 55-2154 (IPA, PEUFR); 19/X/1955, fl., Lima 55-2198
(PEUFR); 19/X/1955, fl., Andrade-Lima 55-2199 (IPA); 8/V/1968, fl. fr., Andrade-Lima 68-5372 (IPA); 6/III/1993, fl., Miranda et al. 705 (PEUFR); 1/VI/1993, fl., Miranda et al. 785 (HST, PEUFR); 3/VI/1993, fl., Miranda et al. 986 (HST, PEUFR); 1/X/1997, fl. fr., Miranda \& Félix 7957 (HST); 7/IV/1999, fl., Miranda 3187 (HST); s.d., fl. fr., Miranda et al. 918 (HST, PEUFR); s.d., fl. fr., R.L.dR. 14 (IPA); Floresta, 4/III/1989, fl., Araújo 23 (IPA); Garanhuns, 1986, fl., Bedi 315 (IPA); Gravatá, 18/I/1994, fl. fr., Miranda 1205 (HST); 18/I/1994, fl., Miranda 1205 (PEUFR); 1/VIII/1996, fl., Lira 81 (HST); 25/V/2006, fl. fr., Abreu et al. 283 (PEUFR); s.d., fl., Leal \& Silva 173 (RB, UB); Fazenda Nova, 16/VI/1995, fl., Rodal et al. 590 (PEUFR); Ibimirim, 17/VI/2005, fl. fr., Melo \& Silva 546 (PEUFR); 2/VII/2006, fl. fr., Abreu et al. 347 (PEUFR); Jatobá, 28/V/1997, fr., Costa e Silva 1240 (PEUFR); Lajedo, 10/IV/2006, fl., Abreu \& Alves 231 (PEUFR); Ouricuri, 9/III/1982, fl., Lima et al. 30 (PEUFR); Pesqueira, 19/IV/2002, fl., Silva et al. s.n. (UFP40452); Petrolândia, 2/VIII/1986, fl., Ataide 728 (IPA); Petrolina, 13/III/1979, fl., Andrade-Lima 79-9324 (IPA); 1979, fl., Andrade-Lima 79-9413 (IPA); Pombos, 3/II/1981, fl., Krapovickas et al 38008 (IPA); Recife, 10/XI/1994, fl. fr., Pereira et al. s.n. (IPA-56824); Saloá, 29/VI/2006, fl. fr., Abreu et al. 306 (PEUFR); São Bento do Una, 26/IV/1971, fl., Coceiro s.n. (IPA-20057); São Caetano, 25/IV/1971, fl., Pontual 71-1107 (PEUFR); São João, 11/IV/2006, fl. fr., Abreu \& Alves 246 (PEUFR); São José do Belmonte, 16/III/1965, fl., Sobrinho 17 (PEUFR); Tacaratu, 30/XI/1996, fl. fr., Oliveira et al. 75 (HST); Terra Rica, 19/V/1981, fl. fr., Pontual \& Rodal 811807 (PEUFR); Triunfo, 25/V/1971, fr., Heringer et al. 918 (IPA, PEUFR, UB); 25/II/1986, fl., Lima \& Gallindo 45 (IPA); 16/IV/1986, fl., Lima \& Gallindo 203 (IPA); 10/III/1995, fl. fr., Miranda et al. 2164 (HST); 24/IX/2005, fl. fr., Аbreu 142 (PEUFR); 24/IX/2005, fl. fr., Abreu 151 (PEUFR); Viçosa, 1979, fl., Andrade-Lima 79-9240 (IPA); s.l., 20/IV/1971, fl. fr., Heringer et al. 203 (IPA); s.1., s.d., fl., Lima \& Cavalcanti s.n. (IPA-31058).

Ocorrência no Norte do Paraguai, Bolívia, Noroeste da Argentina e Brasil nas regiões Nordeste (BA, CE, PB, PE, PI, RN), Sudeste (MG, RJ) e CentroOeste (MT) preferencialmente em locais de elevada altitude (Lourteig 1994). Em Pernambuco, ocorre nas zonas da Mata Seca, em florestas, e nas das Caatingas, subzonas do Agreste e Sertão, sendo freqüente em serras, em vegetação de caatinga e em florestas 
montanas. O hábito arbustivo (até $2 \mathrm{~m}$ alt.), os folíolos discolores, seríceos na face inferior, e as cápsulas ovóide-globosas com uma semente por lóculo, são características que a distinguem das demais espécies estudadas. Conhecida como "velame-vultoso", floresce e frutifica durante o ano inteiro em Pernambuco.

9. Oxalis triangularis A. St-Hil., Fl. Bras. Merid. (quarto ed.) 1:102. 1825.

Fig. 70-74, 75

Ervas bulbosas, ca. $25 \mathrm{~cm}$ alt. Bulbos alongados, 3-6 cm compr., rizomatosos; estolões às vezes numerosos, produzindo bulbilhos secundários; bulbos escamosos, escamas externas 7-10×3-8 mm, membranáceas, oval-arredondadas, 3-nervadas, escamas internas $8-9 \times 6-7 \mathrm{~mm}$, suculentas, ovalarredondadas, com 3 nervuras alaranjadas salientes. Folhas alternas, digitadas, trifolioladas; estípulas ausentes; pecíolo 7-20 cm compr., cilíndrico, glabro a ligeiramente pubescente, vináceo; peciólulo 1,5-2 mm, cilíndrico, viloso; folíolos 2,2-3,8×3,2-6,5 cm, obtriangulares, conduplicados apenas à noite, base obtusa, ápice retuso, margem inteira, faces superior e inferior esverdeadas a vináceas, ambas glabras. Cimas 3-4, 0,1-0,3 cm, umbeliformes, multifloras; pedúculo 8-22,7 cm, cilíndrico, glabro; brácteas 1-2 por flor, 2,5-3 mm compr., ovais a lineares, ápice acuminado, glabras. Flores tristílicas; pedicelo $0,8-2,5 \mathrm{~cm}$, glabro. Sépalas 6-7×1,3-1,5 mm, lanceoladas, esverdeadas, ápice com duas calosidades alaranjadas, glabras. Pétalas 1,4-2,2 cm compr.; unha 1-3 mm, branca, tubo 3-4 mm, rosado com estrias lilases; lobos 1,3-1,7 cm, espatulados, lilases. Flores brevistilas: estames curtos 3-3,5 mm compr., longos 4,5-5 mm compr.; estiletes 0,3-0,5 mm, recurvados; ovário 0,7-1 mm compr.; ginóforo 0,3-0,7 mm. Flores mesostilas: estames curtos 1,5-2 mm compr., longos 5-6 mm compr.; estiletes 1,5-2 mm, eretos, pubescentes; ovário 0,7-1 mm compr.; ginóforo $0,2-0,3 \mathrm{~mm}$. Flores longistilas: estames curtos 2-2,5 mm compr., longos 3,5-3,8 mm compr.; estiletes $4,5 \mathrm{~mm}$, eretos; ovário $0,5-1 \mathrm{~mm}$ compr.; ginóforo $0,2 \mathrm{~mm}$. Estames longos ligulados; androginóforo ausente; anteras 0,5-0,7 mm compr., oblongas. Ovário obclavado, 5-anguloso, glabro; óvulos 6-10 por lóculo; estigmas capitados a bilobados, papilosos. Cápsula 0,9-1,5×0,2-0,4 cm, cilíndricoelipsóide, glabra. Sementes 5-10 por lóculo, 1,5-2× 0,8-1 mm, elipsóides, achatadas dorsiventralmente, longitudinalmente e transversalmente estriadas. Material selecionado: BRASIL. Pernambuco: Gravatá, 26/III/1934, fl. fr., Pickel 3588 (IPA); Ouricuri, 4/V/1971, fl. fr., Heringer et al. 477 (IPA, PEUFR, UB); Recife, 20/V/2006, fl., Abreu \& Silva 280 (PEUFR); Salgueiro, 12/V/1971, fl., Heringer et al. 707 (IPA, PEUFR, UB).

Distribuição na Bolívia, Paraguai, Brasil e Nordeste da Argentina em campos e terrenos úmidos de baixa altitude (Lourteig 2000). No Brasil, ocorre preferencialmente nas regiões sudeste (MG, RJ, SP) e Sul (PR, RS, SC). Em Pernambuco, é encontrada na zona da Mata (Recife), em locais úmidos de jardins e na zona das Caatingas, no Agreste e Sertão, na vegetação de caatinga, em áreas sombreadas, em margem de estradas. Oxalis triangularis pode ser reconhecida por possuir calosidades no ápice das sépalas, pétalas de tubo rosado com estrias lilases, folhagem atraente de coloração esverdeada a vinácea e pelos bulbos alongados, assemelhando-se a rizomas. Em Pernambuco floresce de março a maio. É provável que apresente reprodução vegetativa. É conhecida como "azedinha" ou "trevo".

Lourteig (1994; 2000) reconheceu taxa infraespecíficos para as seguintes espécies: $O$. corniculata (três subespécies e quatro variedades), $O$. debilis (duas variedades), O. frutescens (duas subespécies), $O$. psoraleoides (duas subespécies) e $O$. triangularis (duas subespécies). No entanto, estes taxa não foram adotados no presente artigo pelo fato de terem sido delimitados com base na presença e tipo de indumento, e não estarem relacionados com a distribuição geográfica, o que dificulta o reconhecimento dos mesmos.

Em Pernambuco, parte das espécies tem distribuição preferencial nas zonas da Mata, em floresta atlântica, penetrando na subzona do Agreste, apenas sobre serras, em florestas montanas, como Oxalis cratensis, $O$. hedysarifolia e $O$. corniculata. As espécies $O$. triangularis e $O$. frutescens possuem distribuição desde as zonas do Litoral e Mata até o inicio do Sertão. Oxalis divaricata distribui-se nas subzonas do Agreste e Sertão, ocorrendo também no Arquipélago de Fernando de Noronha. Oxalis psoraleoides apresenta ampla distribuição no Estado, enquanto $O$. debilis é restrita à subzona do Agreste e O. glaucescens é a única com distribuição exclusiva nas caatingas sobre sedimentos arenosos, na subzona do Sertão (Fig. 75). 


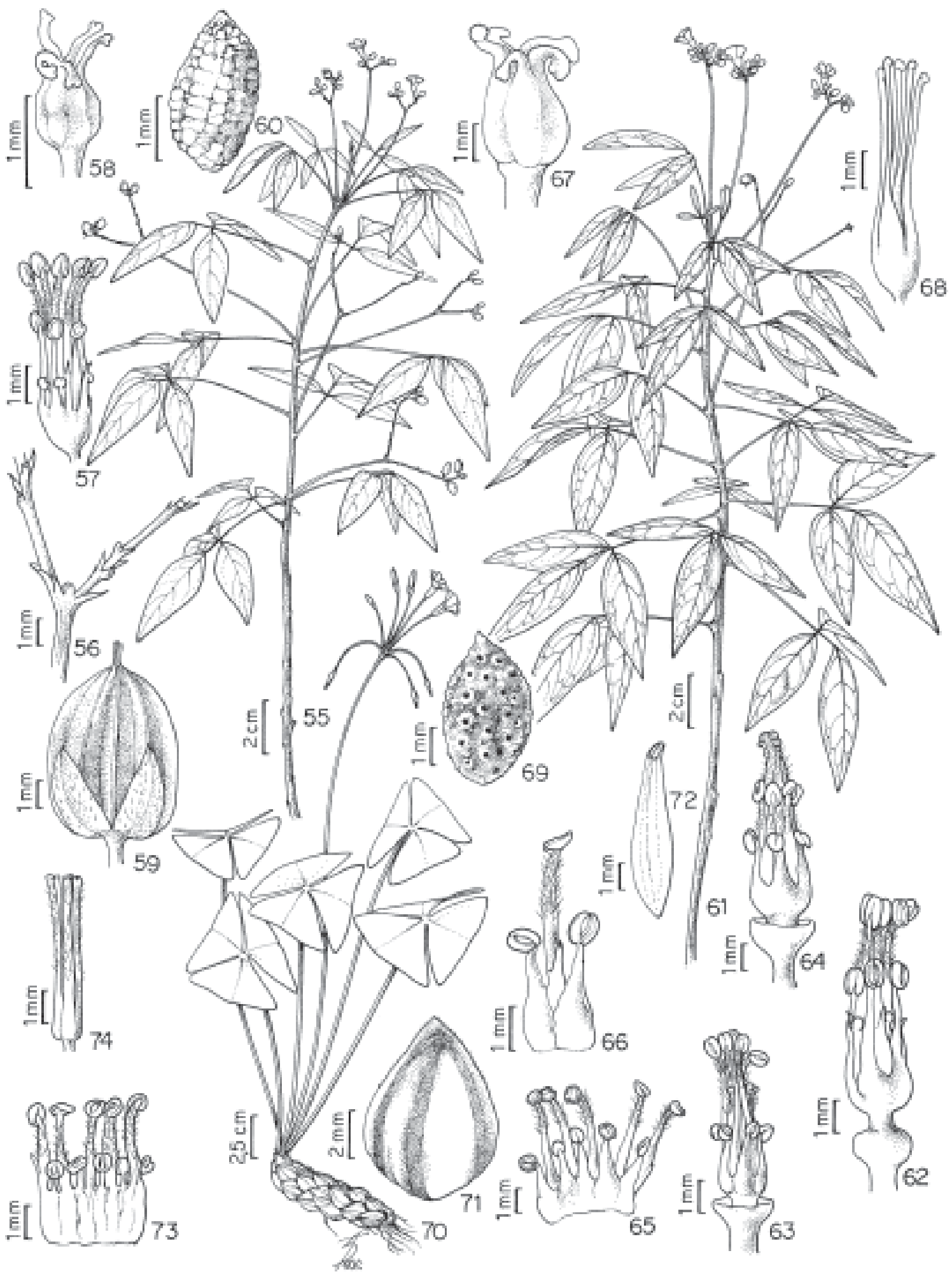

Figuras 55-74. Oxalis hedysarifolia: 55. Ramo florido. 56. Inflorescência detalhe do ápice do pedúnculo floral. 57. Flor brevistila, detalhe do androceu e gineceu. 58. Gineceu, flor brevistila. 59. Fruto. 60. Semente (M.C. Abreu 212). O. psoraleoides: 61. Ramo florido. 62. Flor brevistila, detalhe do androceu e gineceu. 63. Flor mesostila, detalhe do androceu e gineceu. 64. Flor longistila, detalhe do androceu e gineceu. 65. Androceu. 66. Androceu, detalhe do estame longo com indumento e lígula. 67. Gineceu, flor brevistila. 68. Gineceu, flor longistila. 69. Semente (M.C. Abreu 283). O. triangularis: 70. Hábito. 71. Escama interna do bulbo. 72. Sépala, evidenciando calosidade. 73. Androceu. 74. Gineceu (M.C. Abreu 280). 

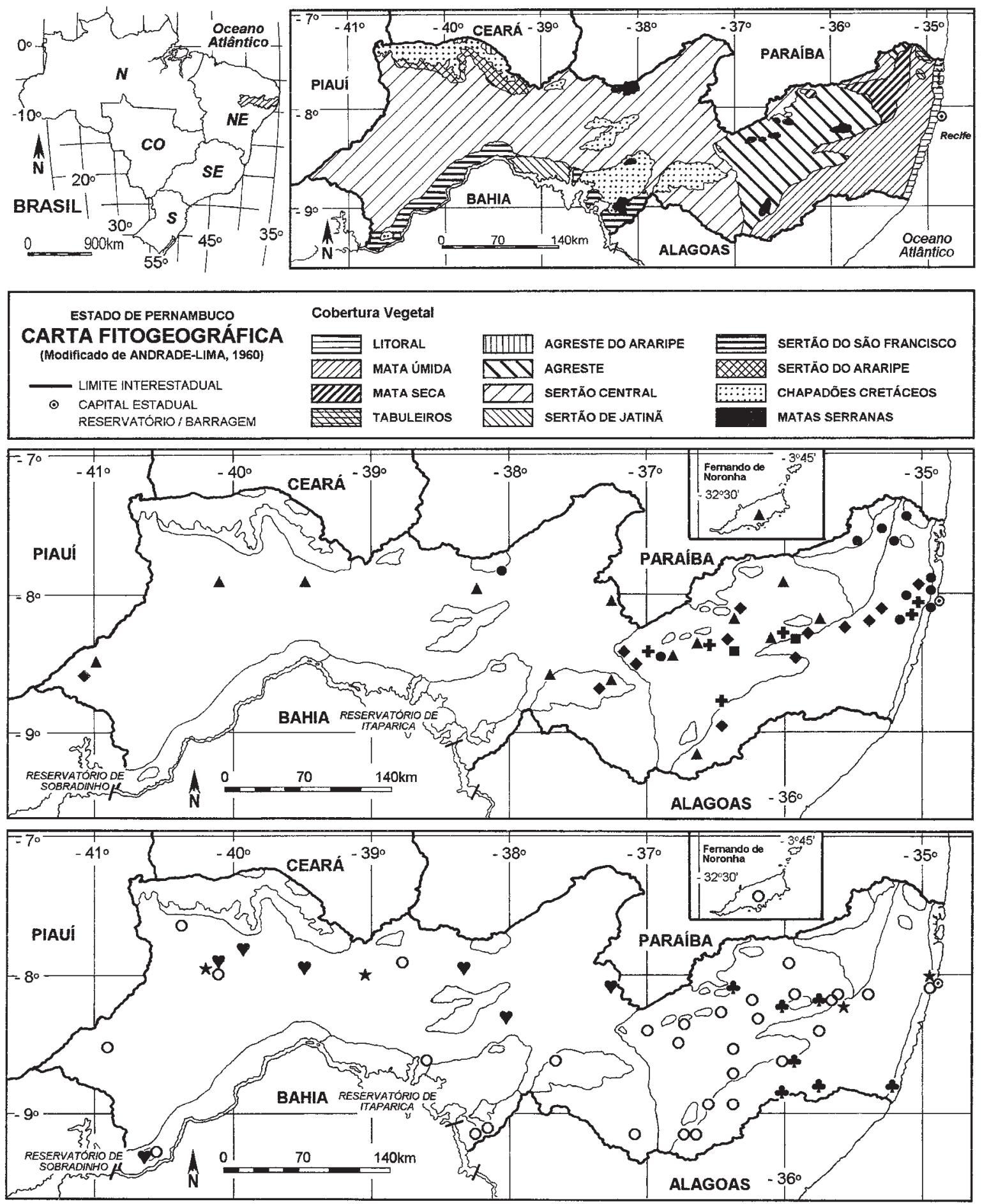

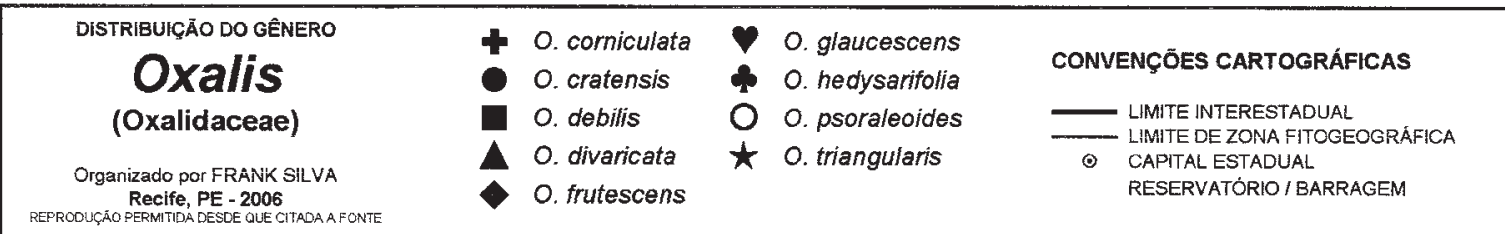

Figura 75. Mapas de distribuição geográfica das espécies de Oxalis L. no Estado de Pernambuco. 


\section{Agradecimentos}

Ao Conselho Nacional de Desenvolvimento Científico e Tecnológico (CNPq), pela bolsa de estudos concedida à primeira autora; ao Programa de PósGraduação em Botânica-UFRPE, pelo apoio institucional; a Franck Silva, pelo auxilio nas ilustrações, aos curadores dos herbários citados, pelo empréstimo e envio de material, aos dois assessores pelas sugestões inseridas ao texto.

\section{Referências bibliográficas}

Andrade-Lima, D. 1960. Estudos fitogeográficos de Pernambuco. Arquivos do Instituto de Pesquisas Agronômicas 5: 305-341.

APG II. 2003. An update of the Angiosperm Phylogeny Group classification for the orders and families of flowering plants: APG II. Botanical Journal of the Linnean Society 141: 399-436.

Barroso, G.M.; Peixoto, A.L.; Ichaso, C.L.F.; Guimarães, E.F. \& Costa, C.G. 1991. Oxalidaceae. Pp. 312-315. In: Sistemática de Angiospermas do Brasil. Viçosa, UFV.v II.

Bell, A.C. 1991. Plant Form: an illustrated guide to flowering plant morphology. Oxford, Oxford University Press.

Brummitt, R.F. \& Powell, C.E. 1992. Authors of plant names. Londres, Royal Botanic Gardens-Kew.

Burger, W. 1991. Oxalidaceae. In: Flora Costaricensis. Fieldiana: Botany 28: 2-16.

Candolle, A.P. 1824. Oxalideae. In: Prodromus Systematis Naturalis 1: 689-702.

Conceição, A.A. \& Giulietti, A.M. 1998. Flora da Serra do Cipó, Minas Gerais: Oxalidaceae. Boletim de Botânica da Universidade de São Paulo 17: 115-122.

Cronquist. A. 1988. The evolution and classification of flowering plants. $2^{\text {nd }} \mathrm{ed}$. New York, The New York Botanical Garden.

Eiten, G. 1963. Taxonomy and Regional Variation of Oxalis section Corniculatae. I. Introduction, Keys and Synopsis of the Species. The American Midland Naturalist 69: 257-309.

Endlicher, S.L. 1840. Oxalideae. In: Genera Plantarum: 1171-1173. Vienna.

Fiaschi, P. \& Conceição, A.A. 2005. Oxalidaceae. Pp. 301-315. In: M.G.L. Wanderley; G.J. Shepherd; T.S. Melhem \& A.M. Giulietti (coords.). Flora Fanerogâmica do Estado de São Paulo. v.4. São Paulo, FAPESP, Rima.

Harris, J.G. \& Harris, M.W. 1994. Plant identification terminology. $2^{\text {nd }}$ ed. An illustrated glossary. Spring Lake.

Holmgren, P.K.; Holmgren, N.H. \& Barnett, L.C. 1990. Index Herbariorum, part 1: the Herbaria of the World. New York, New York Botanical Garden.

Jacquin, N.J.V. 1794. Oxalis monographia. Pp. 1-120. Vienna, Iconibus illustrata.
Judd, W.S.; Campbell, C.S.; Kellogg, E.A. \& Stevens, P.F. 1999. Plant Systematics: a phylogenetic approach. Massachusetts, Sinauer Associates, Inc.

Knuth, R. 1930. Oxalidaceae. In: A. Engler (ed.). Das Pflanzenreich Regni Vegetabilis Conspectus. IV. 130: 1-481. Leipzig.

Kunth, C.S. 1822. Geraniaceae. In: A von Humboldt; A. Bonpland \& C.S. Kunth. Nova Genera et Species Plantarum 5: 228-252.

Lawrence, G.H.M. 1973. Taxonomia das plantas vasculares. v. I. Lisboa, Fundação Calouste Gulbenkian.

Linnaeus, C., 1753. Oxalis. In: Species Plantarum 1: 433-435. Holmiae.

Lourteig, A. 1975. Oxalidaceae extra-austroamericanae I. Oxalis L. Sectio Thamnoxys Planchon. Phytologia 29: 449-471.

Lourteig, A. 1979. Oxalidaceae extra-austroamericanae II. Oxalis L. Sectio Corniculatae DC. Phytologia 42: 57-198.

Lourteig, A. 1980a. Oxalidaceae In: Flora of Panamá. Annals of the Missouri Botanical Garden 67: 823-850.

Lourteig, A. 1980b. Oxalidaceae extra-austroamericanae III. Oxalis L. Subgenus Monoxalis Lourteig. Phytologia 46: 451-459.

Lourteig, A. 1982. Oxalidaceae extra-austroamericanae IV. Oxalis L. Sectio Articulatae Knuth. Phytologia 50: 130-142.

Lourteig, A. 1983. Oxalidáceas. In: R. Reitz (ed.). Flora Ilustrada Catarinense, parte 1, fascículo Oxal. Itajaí, Santa Catarina.

Lourteig, A. 1994. Oxalis L. Subgênero Thamnoxys (Endl.) Reiche emend. Lourt. Bradea 7: 1-199.

Lourteig, A. 1995. Oxalis L. Subgenus Trifidus Lourt. n. subgen. Bradea 6: 389-395.

Lourteig, A. 2000. Oxalis L. Subgéneros Monoxalis (Small) Lourt., Oxalis y Trifidus Lourt. Bradea 7: 202-629.

Maidana, R.O.; Ferrucci, M.S. \& Dematteis, M. 2005. Las especies de la família Oxalidaceae del Parque Nacional Mburucuyá. Universidad Nacional del Nordeste Comunicaciones Científicas y Tecnológicas. B-045.

Mori, S.A.; Silva, L.A.M.; Lisboa, G. \& Corandin, L. 1989. Manual de manejo do herbário fanerogâmico. Ilhéus, Centro de Pesquisas do Cacau.

Proctor, M.; Yeo, P. \& Lack, A. 1996. The Natural History of Pollination. Great Britain, Harper Collins Publishers.

Progel, A. 1877. Oxalideae. In: C.F.P. Von Martius \& A.G. Eichler (eds.). Flora Brasiliensis 12: 473-520, tab. 102-116. Monachii.

Progel, A. 1879. Oxalidaceae. Pp. 19-24. In: E. Warming. Symbolae ad Floram Brasiliae Centralis Cognoscendam. Vidensk.

Radford, A.E.; Dickson, W.C.; Massey, J.R. \& Bell. C.R. 1974. Vascular Plant Systematics. New York, Happer and Row.

Reiche, K. 1894. Zur Kenntnis der chilenischen Arten der Gattung Oxalis. Botanische Jahrbucher Fur Systematik, Pflanzengeschichte Und Pflanzengeographie 18: 259-305.

Reiche, K. 1898. Oxalidaceae. In: Flora de Chile 1: 302-340. Santiago. 
Robertson, K.R. 1975. The Oxalidaceae in the Southeastern United States. Journal of the Arnold Arboretum 56: 223-239

Romero, M.E.M. 1973. Synopsis de las especies de Oxalis L. de la Mesopotâmia Argentina. Darwiniana 18: 44-69. Saint Hilaire, A. 1825. Geraniaceae. In: Flora Brasiliae Meridionalis 1: 95-135, lám. 21-25. Paris.

Saint Hilaire, A. 1842. Revue de la Flore du Brésil méridional. Annales des Sciences Naturelles Paris 2e. sér 18: 25-30.

Salter, T.M. 1944. The genus Oxalis in South Africa: a taxonomic revision. Journal of South African Botany 1: $1-355$.
Sousa, F.O. \& Bianchini, R.S. 2000. Oxalidaceae. Flora Fanerogâmica do Parque Estadual das Fontes do Ipiranga (São Paulo, Brasil). Hoehnea 27: 117-120.

Thunberg, C.P. 1800. Dissertatio de Oxalide. In: Dissertationes Academicae Upsaliae habitae 2: 73-100. Gottingae.

Veldkamp, J.F. 1971. Oxalidaceae. In: C.G.C.J. van Steenis (ed.). Flora Malesiana 1: 151-178. Leyden.

Zuccarini, J.G. 1825. Monographie der amerikanischen Oxalis - Arten. Denkschriften der Akademie der Wissenschaften München ser. 1. 9: 129-184, lám 1-6. 